\title{
THE VIOLET SNAIL JANTHINA JANTHINA (LINNAEUS, 1578) (MOLLUSCA: GASTROPODA) IS AROUND THE CROATIAN ADRIATIC ISLAND OF LOKRUM AGAIN
}

\author{
Marija Crnčević ${ }^{*}$ \& Ana Bratoš Cetinić ${ }^{2}$ \\ ${ }^{1}$ Public Institution Lokrum Reserve, Od Bosanke 4, HR-20000 Dubrovnik, Croatia \\ ${ }^{2}$ University of Dubrovnik, Department of Aquaculture, Ćira Carića 4, HR-20000 Dubrovnik, Croatia
}

Crnčević, M. \& Bratoš Cetinić, A.: The violet snail Janthina janthina (Linnaeus, 1578) (Mollusca: Gastropoda) is around the Croatian Adriatic island of Lokrum again. Nat. Croat., Vol. 25, No. 2., 327-330, Zagreb, 2016.

A specimen of the violet snail Janthina janthina (Linnaeus, 1578) was collected in Portoč Bay, Lokrum Island, in May 2016, during the beach cleanup and removing of marine debris drift arising from strong winds. The first record of the raft snail J. janthina along the Eastern Adriatic coast was also noticed in the area of Lokrum Island in the middle of the 19th century.

Key words: Janthina janthina, Adriatic Sea, Lokrum, new record

Crnčević, M. \& Bratoš Cetinić, A.: Ljubičasti splavar Janthina janthina (Linnaeus, 1578) (Mollusca: Gastropoda) opet plovi u Jadranu oko Lokruma. Nat. Croat., Vol. 25, No. 2., 327-330, Zagreb, 2016.

Kućica ljubičastog splavara Janthina janthina (Linnaeus, 1578) prikupljena je u uvali Portoč na otoku Lokrumu u svibnju 2016. tijekom uklanjanja otpada naplavljenog jakim vjetrom. Prvi nalaz puža J. janthina na istočnojadranskoj obali zabilježen je također u području otoka Lokruma sredinom 19. stoljeća.

Ključne riječi: Janthina janthina, Jadransko more, Lokrum, novi nalaz

Janthinids are holoplanktonic gastropods that live in the surface layer of the open sea. The snail's fragile dextrous-coiled shell floats upside down, hanging on to a raft of mucous-coated air bubbles. Although they are cosmopolitan species that usually live between $50^{\circ} \mathrm{N}$ and $40^{\circ} \mathrm{S}$, they can drift as far as to British Columbia, England, New Zealand (Lalli \& Gilmer, 1989; Poppe \& Goto, 1991).

According to the World Register of Marine Species (WoRMS), the genus Janthina Röding, 1798 contains 5 valid recent taxa. Four of them, J. exigua Lamarck, 1816; J. janthina (Linnaeus, 1578), J. pallida W. Thompson, 1840 and J. globosa Swainson, 1822, are present in the Mediterranean Sea. By the 1950s, 60 different names in the literature were used for the species of the genus. During the 19th century, five synonymised names for Janthina genus were used (Gofas, 2004; Lalli \& Gilmer, 1989; Laursen, 1953; Mienis \& Spanier, 1987).

Records of Janthina species are made quite often all around the world, but rarely in the Mediterranean and Adriatic. The Croatian naturalist Spiridon Brusina published data regarding the first finding of Janthina species in Adriatic in 1866 (BRusinA, 1866). He identified specimens drifted by currents to Lokrum Island and Dubrovnik Old Port that were collected by the Franciscan monk and pharmacist Ivan Kuzmić (BrusinA, 1907). 


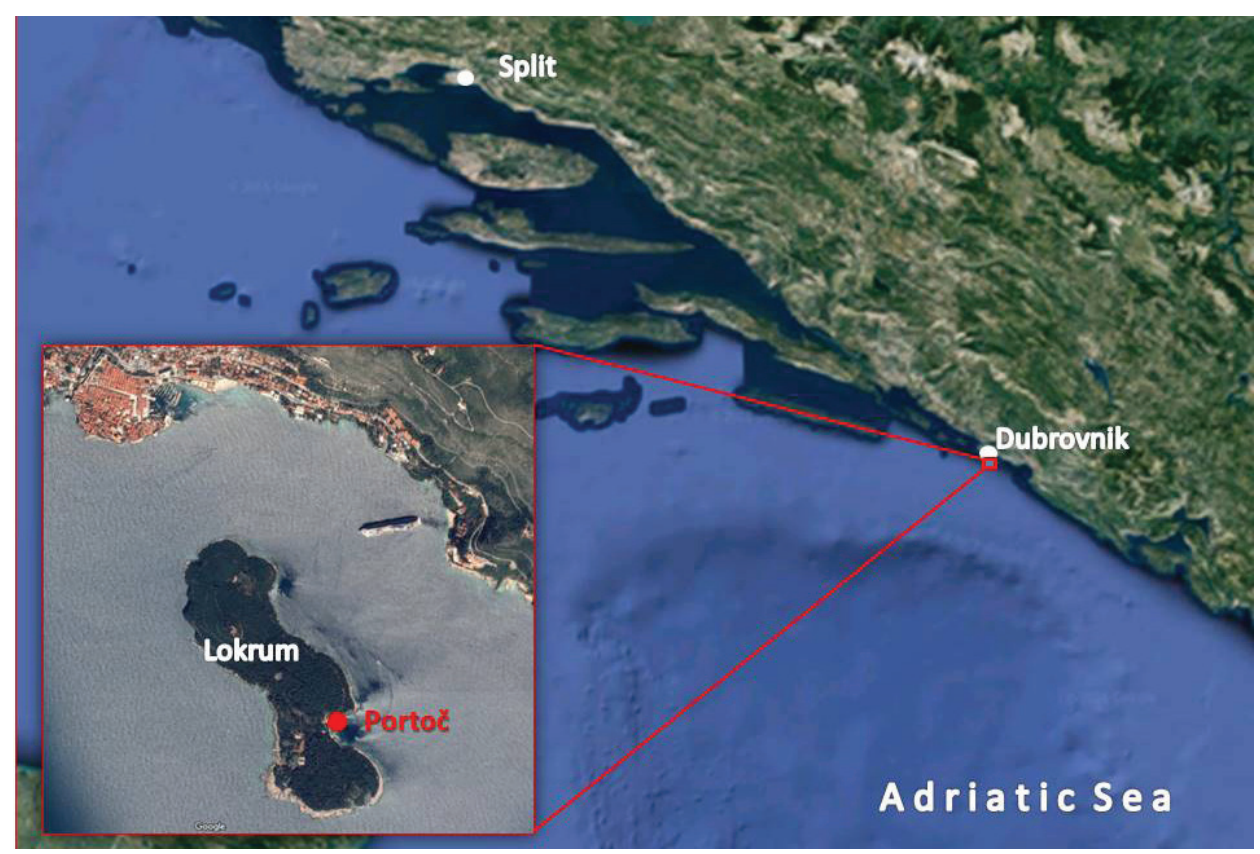

Fig. 1. Geographical position of Lokrum Island

Those specimens of J. janthina and J. globosa are still part of the malacological collection of the Croatian Natural History Museum in Zagreb. The collection contains five specimens of J. janthina from Lokrum and six from the Adriatic in general, Brusina naming them J. costae Mörch, 1860 and two specimens from Lokrum and two of Adriatic origin of J. globosa, which Brusina attributed to J. nitens (ILIJANić \& STošić, 1972). BRusina (1872) reported that J. globosa (syn. J. prolongata Blainville, 1822) was found in off Hvar Island. During the $20^{\text {th }}$ century, only two specimens of $J$. globosa were recorded in the waters around Rab Island in the northern Adriatic in 1961 (Legac \& Mienis, 2010).

There had been no other records of any other Janthina species until May $2^{\text {nd }} 2016$, when a specimen of J. janthina was found on a gravel beach in Portoč Bay, Lokrum Island (Fig. 1). This area is directly exposed to the northwest oligotrophic current from the Eastern Mediterranean which flows through the Strait of Otranto (OrLić et al., 1992; Zore-Armanda, 1969).

J. janthina can grow up to $40 \mathrm{~mm}$ high and $30 \mathrm{~mm}$ broad, but usually is smaller (Poppe \& Gото, 1991). The width/height ratio gets smaller as the shell grows, but it varies between individuals (WILson \& Wilson, 1956). The specimen found at Lokrum has a height of $20 \mathrm{~mm}$ and a width of $21 \mathrm{~mm}$. The shell is typically coiled and exhibits four blue to violet whorls which are turning darker from the apex to the wide aperture. Inside, the shell surface of the last whorl is very dark, as are the soft parts of the animal (Fig. 2). Since that part of the animal that lives "at the sea surface" is exposed upwards, it is almost invisible to potential predators from the air, as is the lighter part of the shell to predators from the sea. The violet snail's coiled shell is rather fragile; therefore we may not rule out the possibility that there were other broken shells among the marine debris and seaweed on the beach in Portoč Bay that were overlooked. 

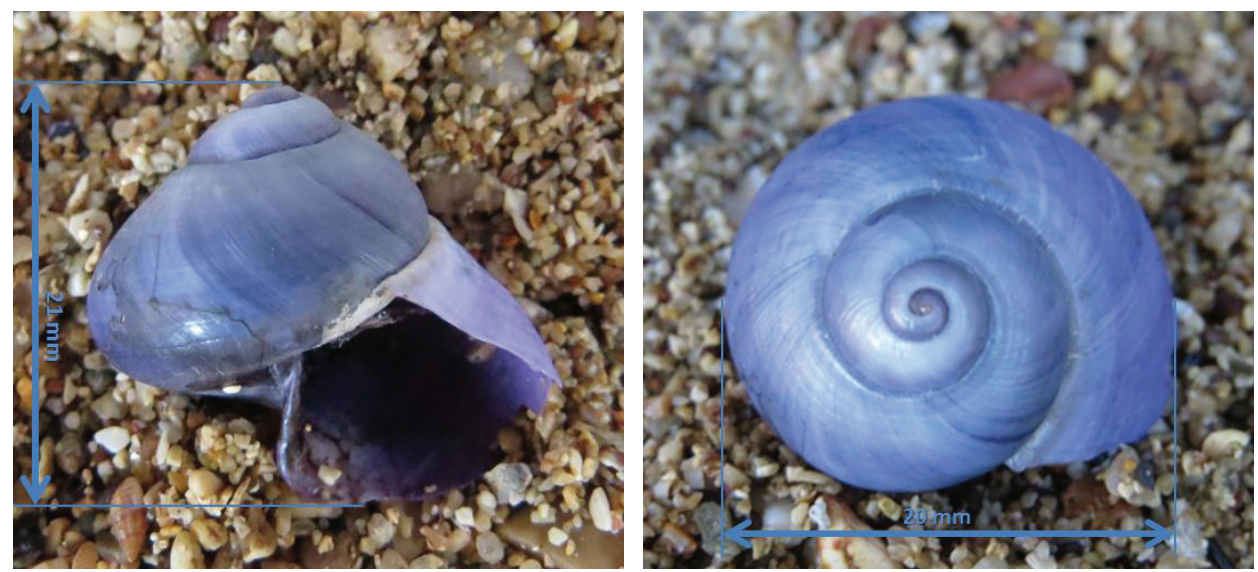

Fig. 2. Two views of the Janthina janthina (Linnaeus, 1578) shell

Bubble rafts with adhering snails form part of the pleuston community and are often found with their preferred prey the jellyfish Velella (Wilson \& Wilson, 1956), Porpita and Physalia (Legac \& Mienis, 2010). We remark that this violet snail was found a week after a bloom of the jellyfish Aurelia aurita (Linnaeus, 1758) that was noticed in Portoč Bay. During the following weeks the occurrence of $A$. aurita was noticed sporadically. A strong south-eastern wind accompanied by waves drifted not only animals that could not resist their force, but also seaweed and marine debris onto the beaches of Lokrum Island. This episode resulted in the Janthina specimen being found during the cleaning of the beach.

Despite the long natural history and research tradition (e.g. BELAMARIć \& ŠERMAN, 1989; BRusina, 1866, 1872; Špan et al., 1989), desipite the protected status of Lokrum Island and its marine zone (Croatian Nature Protection Act (Anonymous, 2013b), Croatian Regulation on Ecological Network (ANONYmous, 2013a, 2015) and UNESCO World Heritage List (AnONymous, 2016) there is no collection that represents the values of the island. This specimen of violet snail is to be the first object in the natural history collection that will be founded by the Lokrum Reserve.

\section{ACKNOWLEDGEMENTS}

We thank Ms. Zore Kordić, (Lokrum Reserve) who found the violet snail shell on the coast of the Lokrum Island and gave it to the authors of this paper. Special thanks go to Dr Vesna Štamol, Croatian Natural History Museum, Zagreb for her contribution and help with references.

Received October 7, 2016

\section{REFERENCES}

Anonymous, 2013a: Uredba o ekološkoj mreži [Regulation on the Ecological Network]. Narodne novine / Official Gazette 124/2013.

Anonymous, 2013b: Zakon o zaštiti prirode [Nature Protection Act]. Narodne novine / Official Gazette $80 / 2013$. 
Anonymous, 2015: Uredba o ekološkoj mreži [Regulation on the Ecological Network]. Narodne novine / Official Gazette 105/2015.

AnONYMous, 2016: UNESCO World Heritage List http://whc.unesco.org/en/list/95/multiple=1\&unique_ number $=103$

Belamarić, J. \& ŠERman D., 1989: Ekološka studija podmorja Lokruma. Otok Lokrum, Ekološke monografije, Knjiga 1, Hrvatsko ekološko društvo, 361-412.

BRUsina S., 1866: Contribuzione pella fauna dei Molluschi Dalmati. Verhandlungen der kaiserlich-königlichen zoologisch-botanischen Gesellschaft in Wien 16, 1-134.

BRUSINA, S., 1872: Naravoslovne crtice sa sjevero-istočne obale jadranskog mora. Dio prvi. Rad Jugoslavenske akademije znanosti i umjetnosti 19, 105-177.

BRUsina, S., 1907: Naravoslovne crtice sa sjevero-istočne obale Jadranskog mora. Dio četvrti i posljednji, specijalni. XIV. Prilog za faunu trbonožaca Dalmacije, Crne gore i Jadranskog mora. Rad Jugoslavenske akademije znanosti i umjetnosti, 171, 106-177.

Gofas, S., 2004: Janthina Röding, 1798. In: MolluscaBase (2016) Accessed through: World Register of Marine Species at http://www.marinespecies.org/aphia.php?p=taxdetails\&id=138092 on 2016-12-01

Ilijanić, V. \& Sтоšić, M., 1972: Popis zbirke mekušaca (Mollusca) Spiridiona Brusine. Hrvatski narodni zoološki muzej Zagreb, 6, 86 pp.

Lali, C.M. \& Gilmer, R.W., 1989: Pelagic Snails: The Biology of Holoplanktonic Gastropod Mollusks. Stanford University Press, Stanford, California, $259 \mathrm{pp}$.

Laursen, D., 1953: The genus Ianthina. Dana Report 38, 1-41.

Legac, M. \& Mienis, H.K., 2010: New finding of Janthina globosa Swainson, 1822 (Mollusca, Gastropoda) in the eastern part of the Adriatic Sea, Natura Croatica, 19(1), 245-248.

Mienis, H. K. \& Spanier, E., 1987: A review of the family Janthinidae (Mollusca, Gastropoda) in connection with the Tekhelet dye. In E. Spanier (ed.): The Royal Purple and the Biblical Blue Argaman and Tekhelet. The study of Chief Rabbi Dr. Isaac Herzog on the dye industries in Ancient Israel and recent scientific contributions, 197-205, plt. H. Keter Publishing House, Jerusalem.

Orlić, M., Gačić, M. \& La Violette, P.E., 1992: The currents and circulation of the Adriatic Sea. Oceanologica Acta, 15, 109-124.

Poppe, G. T. \& Goтo, Y., 1991: European seashells. Vol. 1. (Polyplacophora, Caudofoveata, Solenogastra, Gastropoda). Verlag Christa Hemmen, Wiesbaden: 352 pp.

Špan, A., PožAr-Domac, A., Antolić, B. \& Belamarić, J., 1989: Bentos litoralnog područja otoka Lokruma. Otok Lokrum, Ekološke monografije, Knjiga 1, Hrvatsko ekološko društvo, 329-360.

Wilson, D.P. \& Wilson, M.A.,1956: A contribution to the biology of Ianthina janthina (L.). Journal of the Marine Biological Association of the United Kingdom, 35 (2), 291-305.

Zore-Armanda, M., 1969: Water exchange between the Adriatic and the eastern Mediterranean. Deep-Sea Research, 16, 171-178.

\section{SAŽETAK \\ Ljubičasti splavar Janthina janthina (Linnaeus, 1578) (Mollusca: Gastropoda) opet plovi u Jadranu oko Lokruma}

\section{Crnčević \& A. Bratoš Cetinić}

Kućica holoplanktonskog puža Janthina janthina (Linnaeus, 1578) prikupljena je u uvali Portoč na otoku Lokrumu u svibnju 2016. tijekom uklanjanja otpada naplavljenog jakim vjetrom. Nalazi vrsta roda Janthina relativno su česti u svijetu, dok su u Jadranu rijetki. Prvi nalaz puža J. janthina na istočnojadranskoj obali zabilježen je sredinom 19. stoljeća u području otoka Lokruma. Iako je Lokrum područje s dugom tradicijom prirodoslovnih istraživanja, ne postoje zbirke koje predstavljaju vrijednosti otoka. Stoga je ovaj primjerak ljubičastog splavara prvi predmet u planiranoj pirodoslovnoj zbirci Rezervata Lokrum. 